\title{
USING ENGLISHLEAP WEBSITE IN TEACHING VOCABULARY: A STUDY AT MADANI ALAUDDIN PAOPAO
}

\author{
Andi Winda Sri Lestari \\ Winda@gmail.com \\ Universitas Islam Negeri Alauddin Makassar \\ Nur Aliyah Nur \\ nuraliyah@uin-alauddin.ac.id. \\ Universitas Islam negeri Alauddin Makassar
}

\begin{abstract}
This paper aims at describing whether Englishleap website is effective in improving students' vocabulary mastery or not. The researcher applied quasi experimental design. The population of this research was the tenth grade students of MA Madani Alauddin Paopao which consisted of 128 students. The researcher took 16 students in experimental class and 16 students in control class. The independent variable of this research was Englishleap website and the dependent variable of this research was Students' vocabulary mastery. The instrument of this research was a written test used in pre-test and post-test. The result of the data indicated that there was a significant difference between students' post-test in experimental class and controlled class. The mean score of post-test (91.25) in experimental class was higher than the mean score of post-test (71.87) in controlled class. From t-test, the researcher found that the value of the t-test (3.93) was higher than t-table (2.043) at the level of significance 0.05 with degree of freedom $(\mathrm{df})=32$. From the result of the research the researcher concluded that the hypothesis was accepted. It means that using Englishleap website was effective in improving students' vocabulary mastery at the tenth grade students of MA Madani Alauddin Paopao. Therefore, English teacher may use the Englishleap website in teaching process, because it can make the learning process more enjoyable, fun and effective.
\end{abstract}

KEYWORDS: Englishleap Website, Vocabulary Mastery

\section{A. INTRODUCTION}

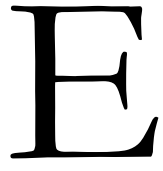

nglish is one of the most important languages in the world; students from all over the world want to be able to speak English fluently for furthering their career prospects. Not only for students but almost the people want to know it. English is also needed by people who work in tourism that is used in hotel, restaurant, guide, tour, travel and anymore.

In learning English, vocabulary is one important element of language that we have to know. Vocabulary is one of the components in English that very important because it is the words that make up a language or the words used or understood by a person (D.J. Henry, 2007). On the other side, vocabulary also has meaning that is all the words that a person knows or uses (Oxford, 2008:495). And then, the vocabulary is one of the language aspects which should be learnt. The examples of vocabularies are drink, banana, January, 
and etc. To improve our speaking we have to memorize many vocabularies in order that our English can be improved. We can see the list of vocabulary in the vocabulary book and also in dictionary. On the other side, we also can learn and build our vocabulary through internet media.

Because of the influence of the developing science and technology, students usually use an internet media to make easier in learning English. Through internet media, we can access many literatures and references of knowledge that we need.

There is a website on the internet to learn English that is called "Englishleap", it is a fun way to improve English comprehension, understand grammar concepts, and build vocabulary and above all (Englishleap.com, 2012). Englishleap is one new startup on the horizon that aims to be the world's biggest community of people looking to learn English language, the startup focuses on spoken English and combines technology to make easier to learn the language online (Kaustubh, 2012). On the other side, Englishleap also focuses on imparting fluency in speaking, reading and writing English. There are many contents of Englishleap, and the one of its contents is Vocabulary.

There are ten subjects on the vocabulary contents, the content are includes: learning root words, prefixes, suffixes, collocations, phrasal verbs, synonyms, antonyms, words meanings, foreign language words, and foreign phrases used in English.

In any reason, most of the teacher and also the students prefer using internet media more than using book. So, all of the explanations above are the aim of the research is to know how effective the internet media toward learning English. Is it the best more than the others?

On the other side, the benefit of internet media for students is, it can make them easy to understand, not only for students but internet media online also can make the teacher easy to access many references from internet and also can teach English especially vocabulary with the easier method.

Based on the previous statement, the researcher is interested in conducting a research under title: "The Effectiveness of Englishleap Website in Improving students' Vocabulary Mastery at the Tenth Grade Students of MA Madani Alauddin Paopao".

\section{B. REVIEW OF LITERATURE}

Englishleap is an English website on the internet to learn English., it is a fun way to improve English comperehension, understand grammar concepts, build vocabulary and above all (Englishleap.cpm, 2012). Englishleap is also a new startup on the horizon that aims to be the world's biggest community of people looking to learn the English language. Englishleap focuses on imparting fluency in speaking, reading and writing English (Kaustubh, 2012) 
Andi Winda Lestari, Nur Aliyah Nur, Using Englishleap Website in Teaching Vocabulary...

Englishleap has some contents, they are : 1) Tips on improving English, 2) A collection of learners' experience on how they learnt English, 3) Help with English grammar, 4) Punctuation Rules, 5) Vocabulary, 6) Common mistakes non-native English speakers usually make, 7) Articles on learning English using your mother tongue, 8) How to get that dream job and tips on interview preparatio, 9) English Exercises to test your language skills

While, in the vocabulary contents, there are ten subjects in there, the contents are includes learning root words, Prefixes, Suffixes, Collocations, Phrasal verbs, Synonims, Antonyms, Word Meanings, Foreign language Words, Foreign Phrases Used in English

EnglishLeap teaches English in three learning layers. The first layer is the selflearning course which the user can use to practise spoken English with the computer. The user can take part in simulated conversation, record his voice and compare his recording with an expert. The second layer is teacher led classes. Users can login to Englishleap.com and join virtual classes. These classes are designed to give maximum spoken English practice to the learners. The third layer is social learning where the learners can talk to other English learners to get additional speaking practice. And there are two plans that the user can choose from - free users have access to a grammar improvement course and selfpractice exercises. Paid users get access to the complete self-learning course, 12 teacher led grammar classes and unlimited conversation classes.

\section{The Contents And Exercise Form Of Englishleap Website}

\begin{tabular}{|c|c|c|c|c|}
\hline Grammar & Vocabulary & Quick tips & Helpful & Language \\
\hline Adjectives & Antonyms & Common Mistakes & Resources & Resources \\
\hline Adverbs & Idions & in Eiglsh & Engish Gramnar & Hind, Tamil. \\
\hline Atticles & Metaphors & English Punctuation & English Vocabulary & Telugu, Urdu, \\
\hline Nouns & Phrasal Verts & Group Discussion & Eng'sh Exercises & Marathi, Kannada. \\
\hline Prepositions & Synonyms & Tips & English Tutorial & Bengali, Gujarati to \\
\hline Tenses & Root Words & Interview & Improve English & English Translation \\
\hline Verbs & & Preparation & Communication & Quiz \\
\hline \multirow[t]{10}{*}{ English Lessons } & & Leam English & How to improve & English to Hindi, \\
\hline & & Pronunciation & Spoken English & Tami, Telugu, \\
\hline & & Resume Writing & Learn English & Urdu Marathi. \\
\hline & & Tips & Online & Kannada, Bengals, \\
\hline & & Spoken English & English Video & Gujarati Transiation \\
\hline & & Tips & Lessons & Quiz: \\
\hline & & & & Leam English \\
\hline & & & & through Hindi \\
\hline & & & & Leam English \\
\hline & & & & Through Tamil \\
\hline
\end{tabular}




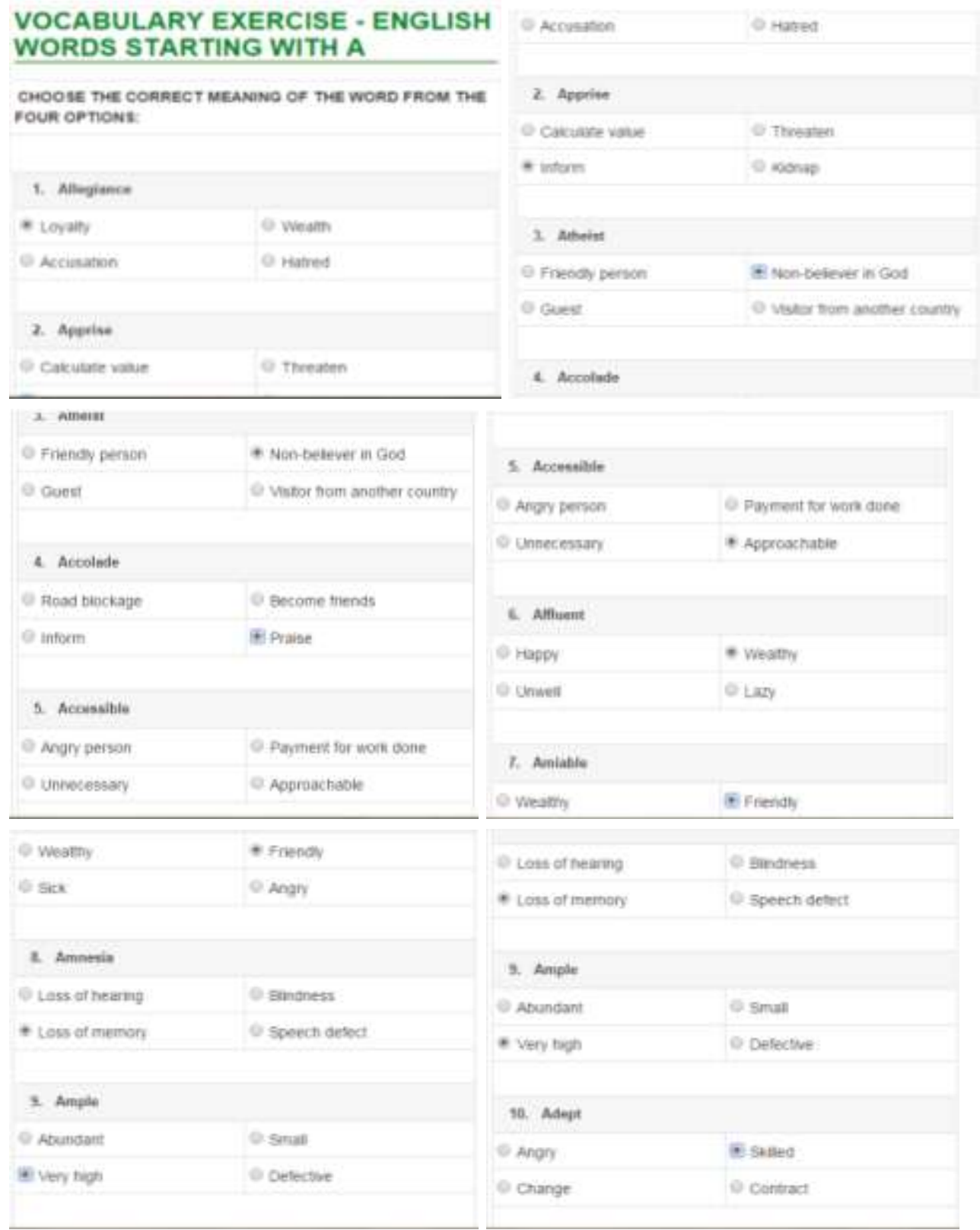

Englishleap is a fun way to improve our knowledge especially in English. There are many subjects in this website which we can be learned and easy to be understood, the explanation of the topics is not too long and complete by the exercise so, if the students have studied they can directly to work the exercise and also can see their score directly. Therefore, the students will be interested in studying English by using the web.

\section{RESEARCH METHOD}

The research design used in this research was quasi-experimental design with pre-test and post-test design. The comparison between pre-test and post-test score depend on the success of the treatment that aims at finding out Englishleap website effectiveness in improving students' vocabulary mastery. The dependent variable is the "Students" 
Andi Winda Lestari, Nur Aliyah Nur, Using Englishleap Website in Teaching Vocabulary...

Vocabulary Mastery and the independent variable is the "Englishleap website". The researcher chose both of classes, which consist of 67 students as the sample of the resesarch. The researcher just took 16 students in the class XA as experimental class and 16 students in the class $\mathrm{XB}$ as control class because the researcher saw the level of the students, 8 students who has a high level and 8 students has a low level. The test used was vocabulary test consisting 10 multiple questions.

\section{RESULT OF THE RESEARCH}

After conducting the research, then the researcher put the data in the table below which shows the improving students vocabulary mastery with pre-test and post-test in control class and experimental class.

Table. I

Classification of the score and the rate percentage of students' vocabulary mastery in experimental class (pre-test)

\begin{tabular}{|c|c|c|c|c|}
\hline NO & Classification & Score & Frequency & Percentage \\
\hline 1 & Very Good & $85-100$ & 3 & $18.75 \%$ \\
\hline 2 & Good & $65-84$ & 11 & $68.75 \%$ \\
\hline 3 & Fair & $55-64$ & 1 & $6.25 \%$ \\
\hline 4 & Poor & $35-54$ & 1 & $6.25 \%$ \\
\hline 5 & Very Poor & $10-34$ & - & - \\
\hline
\end{tabular}

Table 1 above showed the classifying score of pre-test in experimental class. The table showed from 16 students, there were $18.75 \%$ in very good level and none of the student who gain very poor level.

Table. 2

Classification of the score and the rate percentage of students' vocabulary mastery in experimental class (post-test)

\begin{tabular}{|c|c|c|c|c|}
\hline NO & Classification & Score & Frequency & Percentage \\
\hline 1 & Very Good & $85-100$ & 13 & $81.25 \%$ \\
\hline 2 & Good & $65-84$ & 3 & $18.75 \%$ \\
\hline 3 & Fair & $55-64$ & - & - \\
\hline 4 & Poor & $35-54$ & - & - \\
\hline 5 & Very Poor & $10-34$ & - & - \\
\hline
\end{tabular}

While the data of post-test in control class shows, from 16 students there were no students who gain very poor, poor, and fair level, 3 students in good level, it means that there were $81.25 \%$ students in very good level. 
Table. 3

Classification of the score and the rate percentage of students' vocabulary mastery in control class (pre-test)

\begin{tabular}{|c|c|c|c|c|}
\hline NO & Classification & Score & Frequency & Percentage \\
\hline 1 & Very Good & $85-100$ & 1 & $6.25 \%$ \\
\hline 2 & Good & $65-84$ & 9 & $56.25 \%$ \\
\hline 3 & Fair & $55-64$ & 5 & $31.25 \%$ \\
\hline 4 & Poor & $35-54$ & 1 & $6.25 \%$ \\
\hline 5 & Very Poor & $10-34$ & - & - \\
\hline
\end{tabular}

Table 3 above showed the result from pre-test in control class. In the table we can see no one student in very poor level, 9 students in good level, 5 students in fair level and one student in poor and very good level

Table. 4

Classification of the score and the rate percentage of students' vocabulary mastery in control class (post-test)

\begin{tabular}{|c|c|c|c|c|}
\hline NO & Classification & Score & Frequency & Percentage \\
\hline 1 & Very Good & $85-100$ & 4 & $25 \%$ \\
\hline 2 & Good & $65-84$ & 7 & $43.75 \%$ \\
\hline 3 & Fair & $55-64$ & 4 & $25 \%$ \\
\hline 4 & Poor & $35-54$ & 1 & $6.25 \%$ \\
\hline 5 & Very Poor & $10-34$ & - & - \\
\hline
\end{tabular}

From the post-test, the data showed there were only 4 students with $25 \%$ in very good level, 7 students in good level, 4 students in fair level, one student in poor level and no one of the student in very poor level.

Based on the result from table 2 until 5, it can be concluded that the students' vocabulary did not improve significantly. The score of students still changed from the posttest and pre-test.

1. The Mean score and Standard deviation

Table. 5

Classification of the Mean score and standard deviation of Experimental and Control class

\begin{tabular}{|c|c|c|c|c|c|c|c|}
\hline \multicolumn{3}{|c|}{ Experimental Class } & \multicolumn{4}{c|}{ Control Class } \\
\hline \multicolumn{2}{|c|}{ Pre-test } & \multicolumn{2}{c|}{ Post-test } & \multicolumn{2}{c|}{ Pre-test } & \multicolumn{2}{c|}{ Post-test } \\
\hline MS & SD & MS & SD & MS & SD & MS & SD \\
\hline 75.62 & 10.93 & 91.25 & 11.47 & 68.75 & 12.04 & 71.87 & 16.00 \\
\hline
\end{tabular}


Andi Winda Lestari, Nur Aliyah Nur, Using Englisbleap Website in Teaching Vocabulary...

The table above showed the mean score of the students' and standard deviation result. In this result, the researcher showed the difference of score between experimental class and control class which indicated by the improvement of the students' mean score. The pre-test and post-test of the mean score and standard deviation both of them have an improving score.

Data got from t-test in pretest at level level of significance $a=0.5$ and the degree of freedom $(\mathrm{df})\left(\mathrm{N}_{1}+\mathrm{N}_{2}\right)=(16+16)=32$, showed that the t-test value was 1.68 and the $\mathrm{t}$ table value was 2.043 , it means that the value of the $\mathrm{t}$-test was lower than $\mathrm{t}$-table. It means that there is no differences of means score between experiment and control class. While the result of $t$-test in posttest at the level of significance $a=0.5$ and the degree of freedom (df) $\left(\mathrm{N}_{1}+\mathrm{N}_{2}\right)=(16+16)=32$, showed that the t-test value was 3.93 and the $t$-table value was 2.043 , it means that the value of the t-test was higher than $t$-table. It means that there was a significant difference between score in pretest and posttest.

Based on findings above, showed that the mean score of pre-test and post-test in both of class were increased. It means, Englishleap website is effective because can makes the students' vocabulary mastery improved. This finding is related to Kenworthy's research that using internet can develop the person English skill. The students can mastery all of the material faster, example in vocabulary skill, the students' easy to understand all of the vocabularies, and then in listening skill, the students easy to understand the meaning of the dialog which they was listened. As the result, Kenworthy makes a conclusion that using internet can develop the person English skills.

\section{E. CONCLUSION}

The research conclusion was presented according to the data which have been analyzed in the previous chapter. The data analysis is about the effectiveness of using Englishleap website in improving students vocabulary mastery at the tenth grade students at MA Madani Alauddin Paopao, It can be concluded that the students from experimental class was better after giving the treatment by using Englishleap website. Like in experimental class, the students in control class also have an improving after the researcher taught the English with verbal explanation. It showed from the improving of mean score in both of class.

We can see the improvement of the mean score in Experimental class before giving a treatment was 75.62 and after giving a treatment was 91.25. While, the mean score in Control class before giving a treatment was 68.75 and after giving a treatment was 71.87

The hypothesis result also showed the improving from the students. The research showed that the t-test value was higher than $\mathrm{t}$-table on pre-test and post-test. The t-test value on pre-test was 1.68 and the t-test value on post-test was 3.93 while the t-table value in both of class was 2.043. So, the researcher concluded that the hypothesis was accepted. 
It means that using Englishleap website was effective in improving students' vocabulary mastery at the tenth grade students of MA Madani Alauddin Paopao.

\section{REFERENCES}

Aisyah, S. (2002) Using Selected Materials in Teaching English Vocabulary to The Fifth Grade Students of SD Inpres BTN IKIP 1 Makassar. Thesis FBS UNM Makassar, 2002.

Arikuto, S. (2006) Prosedur Penelitian Suatu Pendekatan Praktik. Jakarta: Rieka Cipta.

Asriaman (2011). Teaching Vocabulary by Using Frontloading Method at SMP 1 Wajo. Thesis FTK UIN Alauddin Makassar, 2011.

Englishleap.com. (2012) Englishleap's free resources section.

Gay, L.R. (2006). Educational Research: Compotensies for Anlaysis and Application. London: Charles E. Merill Publishing Company.

Gove, Philip B. (1966). Webster's Third New International Dictionary. Massachussettes: G. C Meriam Company, 1966.

Henry, D. J. (2007) Mastering Vocabulary. Pearson education, 2007.

Kasim, K. (2001). Teaching English Vocabulary for Young Learners by Using Classroom Simulation Games. Thesis FBS UNM Makassar, 2001.

Kartal, E. (2005) The Internet and Autonomous Language Learning: A Typology of Suggested Aids". The Turkish Online Journal of Educational Technology-TOJET, Vol. 4. 2005. pp. $54-58$

Katdare, K. (2012) Englishleap-Learn to Read Write \& Speak English Online. Published on May,1,2012.

Kenworthy, R. C. (2015) Developing Writing Skills in a Foreign language via the internet. The internet TESL Journal, 10 (10). Retrieved from http://iteslj.org/Techniques/Kenworth-WritingSkills.html. On April, 12, 2015.

Kustaryo, S. (1998). Reading Techniques for College Students. Jakarta: Departemen Pendidikan dan Kebudayaan. Dirjen Dikti. Proyek Pengembangan Lembaga Pendidikan Tenaga Kependidikan.

Nurbing. (2000) Using Group Discussion to Activate Students to Speak English. Thesis FBS UNM Makassar.

Nomass, B. (2013) The Impact of Using Technology in Teaching English as a Second Language. English Language and Literature Studies. Retrieved from http://dx.doi.org/10.5539/ells.v3n1p111. Published on February 22, 2013.

Oxford. (2008) Oxford Learner's Pocket Grammar: Fourth Edition. Oxford: Oxford University Press, 2008.

Sudjana. (2008). Dasar-Dasar Proses Belajar Mengajar. Bandung: Sinar Baru Algesindo, 2008. 
Andi Winda Lestari, Nur Aliyah Nur, Using Englishleap Website in Teaching Vocabulary...

Sugiyono (2014) Metode Penelitian Kuantitatif Kualitatif dan R\&D. Bandung: Penerbit Alfabeta Bandung.

Sunardi (2011). Internet Dalam Pembelajaran Bahasa Inggris. Seminar Nasional Teknologi, Informasi \& Komunikasi Terapan 2011, 2011.

Wallace, Mechael J. (1998) Teaching Vocabulary ELBS. New York: Oxford University Press Inc. 1989. 